\title{
Identification of Sakura interspecific hybrids in Prunus collections
}

\author{
Ilya Stepanov*, Ilnur Balapanov, and Anna Drygina \\ North Caucasus Federal Scientific Center of horticulture, viticulture and winemaking, Krasnodar, \\ 350901, Russia
}

\begin{abstract}
The use of IRAP and ISSR markers for the genetic analysis of Cerasus and Padus samples from the NCFRCHVW collection made it possible to establish the collection genetic structure and identify interspecific hybrids of cherry trees. Clustering of genotyped samples revealed 4 main clusters: 1) Bird cherry; 2) Cherries; 3) Interspecific hybrids of sakura; 4) Sakura. Most of the hybrid forms of sakura and cherries have formed a separate group, which is different from both sour and sweet cherry varieties, and from the classic sakura varieties. Also, some samples were identified that were assigned to groups that were not typical for them. These samples include the genotype of the Sibirskaya krasavitsa bird cherry, AI72 rootstock, Podbelskaya cherry, Polskaya sakura and ornamental cherry Rexii. In general, ISSR and IRAP markers have demonstrated their effectiveness as tools for genetic analysis of Prunus collections and identification of genotypes arising in the course of interspecific hybridization.
\end{abstract}

\section{Introduction}

The using of DNA marker analysis methods in genetic studies of gene pools and collections of cultivated plants makes it possible to assess the plant collections genetic structure. Identify the most genetically distant samples, close or synonymous genotypes, confirm or deny the species belonging of the samples under study. This approach is especially relevant in the study of complex interspecific hybrids collections. It allows evaluating the structure of a collection using genetic information about the contribution of each of the species involved in hybridization.

The genetic diversity description of Prunus collections both at the interspecific and intraspecific levels is a question that has not lost its relevance since the first attempts to use molecular markers of this genus phylogeny. The earliest work in this direction is the study of isoenzymes of 34 Prunus species (subg. Prunus, Amygdalus, Cerasus, and Lithocerasus) [1]. According to the results of isozyme analysis, representatives of the subgenus Cerasus formed a compact group among Prunus species, the similarity of allele frequencies served as an indirect confirmation of the origin of P. cerasus $L$. from P. avium L. and P. fruiticosa Pall, as well as $P$. gonduinii Rehd. from $P$. cerasus $L$. and $P$. avium $L$. Analysis of chloroplast DNA showed that species pairs such as $P$. persica - P. dulcis; $P$. domestica - $P$.

\footnotetext{
* Corresponding author: ivstepanof@gmail.com
} 
salicina; and P. cerasus - P. fruitiosa were monophyletic and that the ancestors of Cerasus separated from other Prunus species early in the genus evolution [2].

Genetic studies of the Cerasus species collections were carried out using various types of molecular markers. Using ISSR markers were study the species genetic structures: Prunus pseudocerasus [3; 4], Prunus cerasus [5], Prunus avium L. [6], Prunus mahaleb L., Prunus incana Pall., Prunus microcarpa Boiss. and Prunus brachypetala Boiss [7]. RAPD markers were used to study the genetics of the following species: P. avium [8], P. mahaleb, $P$. cerasus, $P$. pseudocerasus, $P$. maximowiczii, $P$. serrulata var. lannesiana, $P$. humilis and P. tomentosa [9]. Also, within the subgenus Cerasus, molecular markers such as SSRs [10; 11 and SRAPs [12] were used.

In this work, we used IRAP and ISSR markers for the analysis of Cerasus and Padus samples from the NCFRCHVW collection in order to determine the genetic structure of the collection and identify interspecific hybrids, as well as to assess the prospects of using the selected IRAP and ISSR markers for studying interspecific and intraspecific phylogenetic relationships within these taxa.

\section{Methods}

In the spring of 2019, 49 samples of the subgenera Padus and Cerasus of the genus Prunus were selected for subsequent DNA isolation. The selected samples are shown in Table 1. The sample included 7 bird cherry species ( $P$. padus, $P$. verginiana, and $P$. mahaleb) and 3 interspecific bird cherry hybrids (Hybrid 11, Izmailovsky, LC 52), 10 cherry varieties (P. avium), 5 varieties of common cherry (P. cerasus), 9 ornamental oriental cherries (sakura) of various species origin $P$. serrulata Lindl., $P$. serrulata jamasakura (Lindl.), $P$. lannesiana Carreiere, $P$. incisa, $P$. cerasus rexii , P. cerasus umbraculifera) and 13 complex interspecific sakura hybrids.

DNA extraction from plant material was carried out by a modified CTAB method. For DNA genotyping, ISSR and IRAP markers were selected from various literature sources. In total, 2 ISSR markers and 2 IRAP markers were used. The markers were previously tested on sakura $[13,14]$. PCR was carried out according to the following program: 3 minutes of preliminary denaturation at the temperature of $95^{\circ} \mathrm{C}$; subsequent 35 cycles: denaturation 35 seconds at $95{ }^{\circ} \mathrm{C}$, primer annealing 1 minute at $50{ }^{\circ} \mathrm{C}$ for ISSR and $55{ }^{\circ} \mathrm{C}$ for IRAP, elongation 1.5 minutes at $72{ }^{\circ} \mathrm{C}$, and a final synthesis cycle at $72{ }^{\circ} \mathrm{C}$ for 5 minutes. Concentrations of reagents in the PCR mixture: $2.5 \mu \mathrm{l}$ of 10-x buffer for Taq DNA polymerase, $2.5 \mu \mathrm{l} \mathrm{dNTP}(2.5 \mathrm{mM}), 1$ unit of Taq DNA polymerase activity, $4 \mu 1$ of primer $(4 \mu \mathrm{M})$ and $40-50 \mathrm{ng}$ of total DNA in a total volume of $25 \mu \mathrm{l}$.

For samples genotyping, PCR products electrophoresis carried out at a voltage of $60 \mathrm{~V}$ in a $3.5 \%$ agarose gel stained with ethidium bromide was used. DNA visualization was carried out in ultraviolet light.

Based on the results of genotyping, a binary matrix was constructed for further use of the data in statistic software. For statistical processing of the results of ISSR and IRAP genotyping and analysis of the genetic relationships of the studied gene pool, the PAST version 2.17c program (UPGMA and PCoA analysis) was used. To assess the genetic structure of the sample, the Structure 2.3.4 program (Bayesian analysis) was used. Various values of hypothetical populations from $K=5$ (burn-in period $=200,000 ; 500,000$ iterations) were used in the calculation. 
Table 1. Cherry blossom samples selected for genotyping

\begin{tabular}{|c|c|c|c|}
\hline № & $\begin{array}{l}\text { Abbreviated } \\
\text { form }\end{array}$ & Name & species \\
\hline 1 & $1 \mathrm{Pad}$ & Bird cherry 1 & P. padus coloratus \\
\hline 2 & $2 \mathrm{Pad}$ & Sibirskaya krasavitsa & P. padus \\
\hline 3 & $3 \mathrm{Pad}$ & Bird cherry 2 & P. verginiana \\
\hline 4 & $4 \mathrm{Pad}$ & Bird cherry 3 & $P$. verginiana \\
\hline 5 & $5 \mathrm{Pad}$ & Bird cherry 4-115 & P. verginiana \\
\hline 6 & 6 Pad & Bird cherry 4 & P. verginiana \\
\hline 7 & $7 \mathrm{Pad}$ & Hybrid 11 & $P$. verginiana $x P$ cerasus \\
\hline 8 & $8 \mathrm{CP}$ & Izmaylovskiy (padoceras) & P. cerasus $x$ P. maackii \\
\hline 9 & 9 PC & LC 52 (ceropadus) & P. cerasus $x(P$. cerasus $x$ P. maakii $)$ \\
\hline 10 & $10 \mathrm{Mah}$ & Mahaleb cherry 1 & P. mahaleb \\
\hline 11 & $11 \mathrm{SwCh}$ & Krupnoplodnaya & P. avium \\
\hline 12 & $12 \mathrm{SwCh}$ & Iskra & P. avium \\
\hline 13 & $13 \mathrm{SwCh}$ & Krupnaya zheltaya & P. avium \\
\hline 14 & $14 \mathrm{SwCh}$ & Ultrarannyaya & P. avium \\
\hline 15 & $15 \mathrm{SwCh}$ & Georgia & P. avium \\
\hline 16 & $16 \mathrm{SwCh}$ & Vasilisa & P. avium \\
\hline 17 & $17 \mathrm{SwCh}$ & Summit & P. avium \\
\hline 18 & $18 \mathrm{SwCh}$ & Volshebnitsa & P. avium \\
\hline 19 & $19 \mathrm{SwCh}$ & Krasa Kubani & P. avium \\
\hline 20 & $20 \mathrm{SwCh}$ & Prestizhnaya & P. avium \\
\hline 21 & 21 дюк & Chudo-vishnya & P. avium $\times$ P. cerasus \\
\hline 22 & $22 \mathrm{SrCh}$ & Vladimirskaya & P. cerasus \\
\hline 23 & $23 \mathrm{SrCh}$ & Pamyati Gorshkova & P. cerasus \\
\hline 24 & $24 \mathrm{SrCh}$ & Nord Star & P. cerasus \\
\hline 25 & $25 \mathrm{SrCh}$ & Akvarel & P. cerasus \\
\hline 26 & $26 \mathrm{SrCh}$ & Podbelskaya & P. cerasus \\
\hline 27 & $27 \mathrm{~S}$ & Rexii & P. cerasus rexii \\
\hline 28 & $28 \mathrm{~S}$ & Royal Burgundy & P. serrulata (Lindl.) \\
\hline 29 & $29 \mathrm{~S}$ & Polskaya sakura & P. cerasus umbraculifera \\
\hline 30 & $30 \mathrm{~S}$ & Shirofugen & P. serrulata (Lindl.) \\
\hline 31 & $31 \mathrm{~S}$ & Kanzan & P. serrulata (Lindl.) \\
\hline 32 & $32 \mathrm{~S}$ & Jamasakura & P. serrulata jamasakura (Lindl.) \\
\hline 33 & $33 \mathrm{~S}$ & Shiatsu & P. serrulata (Lindl.) \\
\hline 34 & $34 \mathrm{~S}$ & Kiku-Shidare & P. lannesiana Carreiere \\
\hline 35 & $35 \mathrm{~S}$ & $P$. incisa 2 & P. incisa \\
\hline 36 & $36 \mathrm{~S}$ & P. incisa 1 & P. incisa \\
\hline 37 & $37 \mathrm{SH}$ & Simfoniya nezhnosti & P. incisa $\times$ P. avium \\
\hline 38 & $38 \mathrm{SH}$ & Utrenneye oblako & $P$. incisa $\times P$. avium \\
\hline 39 & $39 \mathrm{SH}$ & Hybrid 1 & P. avium $\times$ P. lannesiana \\
\hline 40 & $40 \mathrm{SH}$ & BI-43-1 & P.cerasus $x$ И 43 (P. avium $x$ P. lannesiana) \\
\hline 41 & $41 \mathrm{SH}$ & BI-43-2 & P.cerasus $x$ И 43 (P. avium $x$ P. lannesiana) \\
\hline 42 & $42 \mathrm{SH}$ & AI5 & P.incisa $\times$ P. avium \\
\hline 43 & $43 \mathrm{SH}$ & Gizela V & (P. cerasus $x$ P. canescens) $x$ P. cerasus \\
\hline 44 & $44 \mathrm{SH}$ & Gizela B & (P. cerasus $x$ P. canescens) $x$ P. cerasus \\
\hline 45 & $45 \mathrm{SH}$ & Hybrid 2 & P. canescens $x$ (P. tomentosa $x P$. avium) \\
\hline 46 & $46 \mathrm{SH}$ & AI 71 & P. cerasus $x$ P.yedoensis \\
\hline 47 & $47 \mathrm{SH}$ & Vesenniy kapriz & $P$. vulgaris $\times P$. lannesiana \\
\hline 48 & $48 \mathrm{SH}$ & AI 72 & P. cerasus $x$ P.yedoensis \\
\hline 49 & $49 \mathrm{SH}$ & VSL 2 & $P$. fruticosa $\times$ P. lannesiana \\
\hline
\end{tabular}




\section{Results and discussion}

Genotyping of 49 samples belonging to different representatives of the subgenus Cerasus and Padus was carried out using 4 multilocus markers: 2 ISSR (UBC 818, UBC 843) and 2 IRAP (Cass1 and Cass2).

The highest polymorphism, expressed in the number of polymorphic DNA fragments, was in the IRAP marker Cass1 (50 DNA fragments), the lowest polymorphism was found in the ISSR marker UBC 843 (34 DNA fragments). In general, the difference between markers in terms of the number of fragments was insignificant; the average value of the number of DNA fragments per marker was 42.75. In total, 171 polymorphic DNA fragments were identified using 4 markers on 49 samples.

\subsection{UPGMA analysis}

On the dendrogram constructed by the UPGMA (unweighted pair group method with arithmetic mean) method, four large clusters can be distinguished (Figure 1). The first cluster includes all genotypes of bird cherry presented in the sample and its hybrids. In this cluster, the grouped position is occupied by two hybrid forms (ceropadus and padocerus), mahaleb cherry and bird cherry hybrid do not stand out from the other bird cherry genotypes. The second large cluster is represented by cherry and cherry varieties. Most cherry varieties form a subcluster separate from sweet cherries, but Chudo-vishnya duke and Podbelskaya sour cherry variety are classified as sweet cherries. The third cluster consists of hybrid forms created from crossing cherries with sakuras (mainly $P$. lannesiana). The fourth cluster is formed by sakura varieties (P. serrulata, P. incise, $P$. umbraculifera, $P$. rexii) and sakura hybrids.

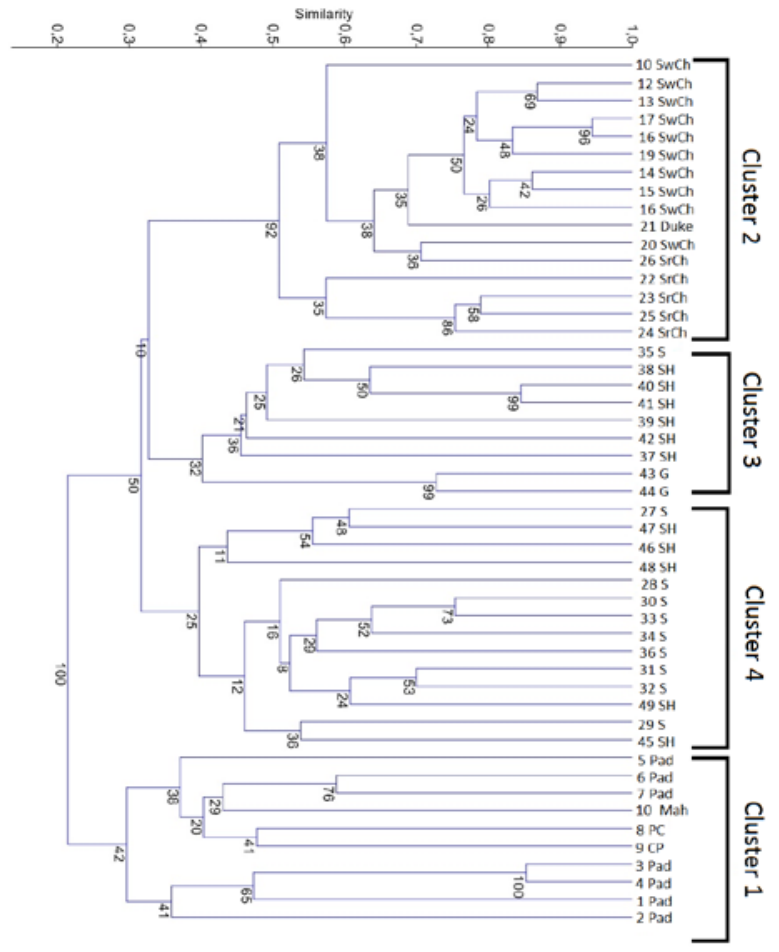

Fig. 1. UPGMA dendrogram of the 49 Prunus samples (Abbreviated form from table 1) 


\subsection{PCoA analysis}

The PCoA (Principle coordinate analysis) method allows obtaining data on the samples distribution on the coordinate plane, which can serve as an additional tool in the analysis of kinship (Figure 2). On the PCoA plot, sakura, cherry, mahaleb cherry and bird cherry species occupy opposite parts of the coordinate plane, while genotypes of hybrid origin tend to the center. This is true primarily for the hybrid sakura forms that occupy the center of the chart. Also, three bird cherry hybrids occupy a position closer to the center relative to the rest of the genotypes of the Padus subgenus (the Sibirskaya krasavitsa was an exception). It is worth noting that the ornamental variety Rexii, referred to as ordinary cherry, but having a number of morphological features that differ from cherries, is located on the graph between cherries and sakura.

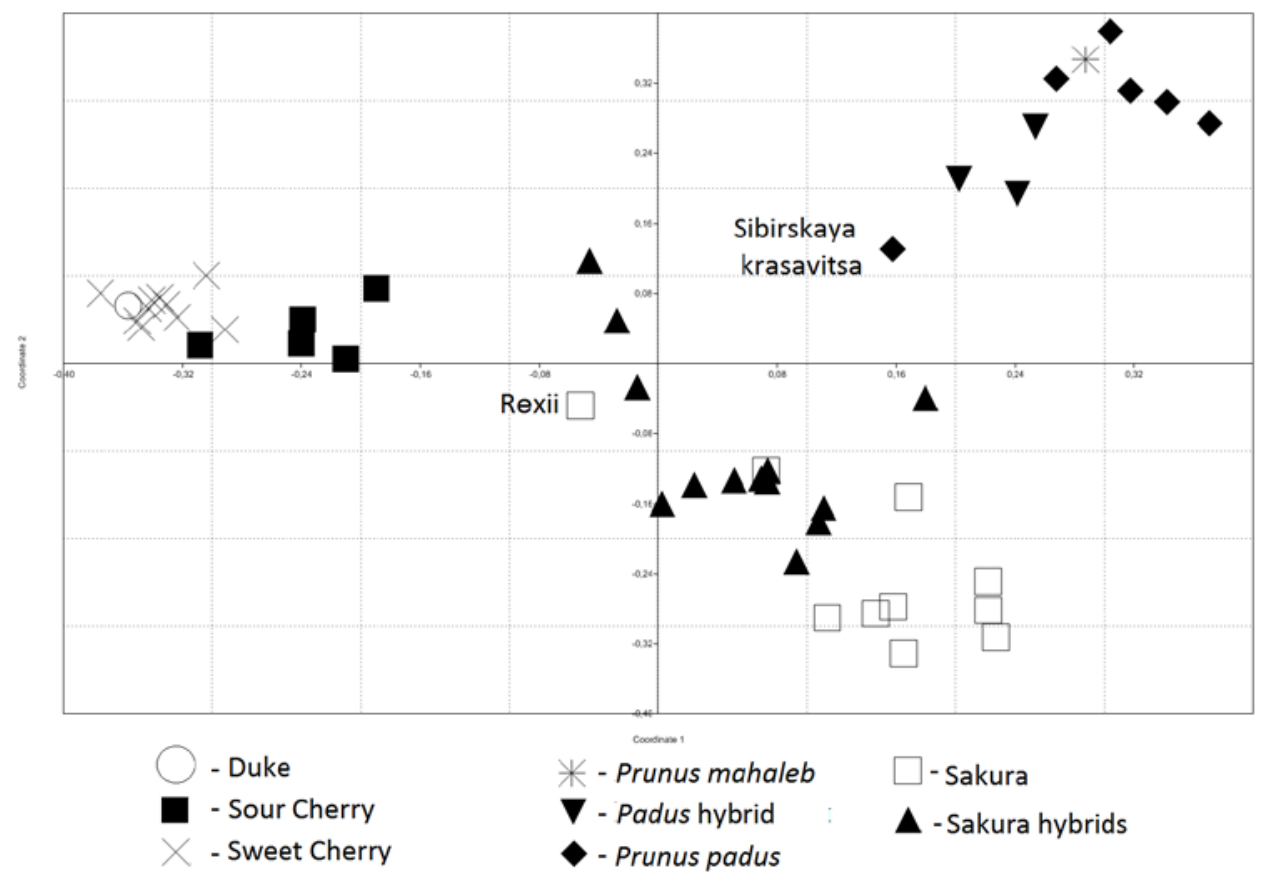

Fig. 2. PCoA plot with 49 Prunus samples

\subsection{Bayesian analysis}

Bayesian analysis is useful in working with populations and hybrids, as it allows identifying samples of mixed origin (Figure 3.). The 1 group prevailed in specimens of bird cherry and mahaleb cherry. The 2 group was characteristic of sweet cherry varieties and was partially present in sour cherries. In turn, the 3 group was typical for sour cherry varieties. Duke Chudo-vishnya included the 3 and 2 groups, which corresponds to its hybrid origin from crossing sweet cherries and sour cherries. The 4 group, as the main one, was present both in sakura and in a some of their hybrid forms. It is worth noting that the hybrid forms of sakura and cherries for the most part had a separate 5 group, which is not typical for either sour cherry and sweet cherry varieties, or for classic sakura varieties. To an insignificant extent, the 5 group is also present in hybrid forms of bird cherry. Also, some samples were identified with the presence of non-characteristic groups in them. These samples include the genotype of the Sibirskaya krasavitsa bird cherry, which combines 
groups 2 and 4, and the AI 72 rootstock, which has group 1, which is characteristic of bird cherry.
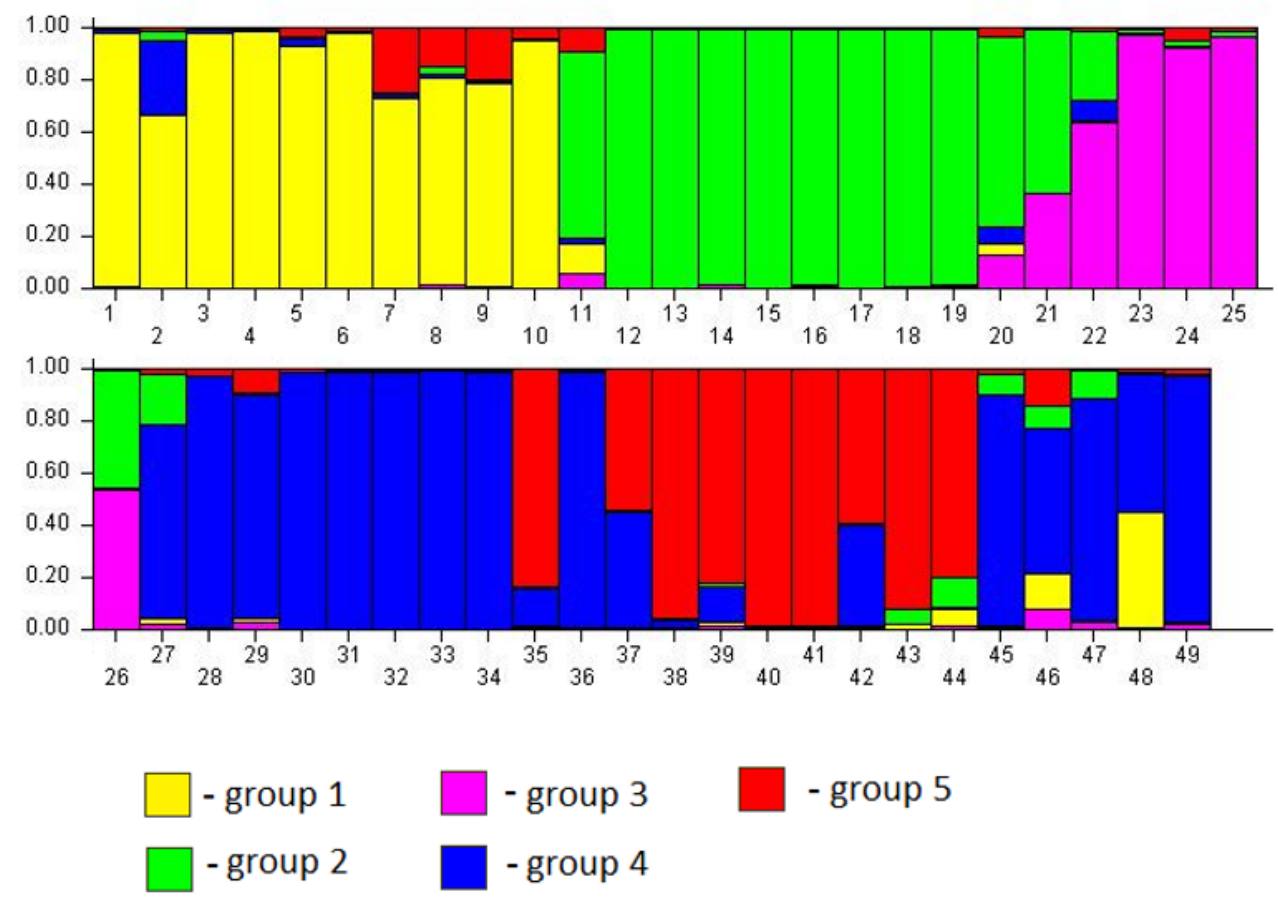

Fig. 3. Bayesian plot with 49 Prunus samples (numbering from table 1)

Thus, the performed genetic analysis made it possible to both confirm the phylogenetic position of the studied species and identify the genotypes which origin requires clarification.

\section{Conclusions}

The complexity and ambiguity of the ranking position of the Cerasus and Padus taxa, as well as the incoming species, requires a detailed genetic study of these plant groups. However, the use of one or a limited number of types of DNA marker systems does not allow obtaining a complete picture of evolutionary processes at the molecular level. For a more complete understanding of the phylogenetic relationships of the studied taxa, it is necessary to expand the marker tools in genetic work. We selected the optimal ISSR and IRAP markers for genetic analysis of 49 samples of cherries, sakura, bird cherry and their interspecific hybrids. To assess the phylogenetic relationship of the samples, we used the main clustering methods that are widely used in modern genetics. Information on the genetic distribution of hybrid forms of stone fruits is of particular value. So if the phylogenetic distribution of species obtained using these markers, in general, serves as a confirmation of the generally recognized genus taxonomy, then information on the position of hybrid forms that have not been previously studied by molecular markers is of particular interest 
The study was carried out with the financial support of the Russian Foundation for Basic Research and the Krasnodar Territory Administration within the framework of the scientific project No. 19-44233011 r_mol_a

\section{References}

1. B.D. Mowrey, D.J. Werner Theoret. Appl. Genetics 80, 129-133 (1990)

2. E. Bortiri, S.H. Oh, J. Jiang, S. Baggett, A. Granger, C. Weeks, M. Buckingham, D. Potter, D.E. Parfitt Syst. Bot. 26 (4), 797-880 (2001)

3. M.M. Li, Y.L. Cai, Z.Q. Qian, G.F. Zhao Genet Resour Crop Evol 56, 455-464 (2009)

4. C. Song, X. Wen, E. Acta Horticulturae Sinica 38, 1531-1538 (2011)

5. A. Lisek, E. Rozpara Journal of Fruit and Ornamental Plant Research. 17, 95 - 106 (2009)

6. Y.I. Ivanovych, K.M. Udovychenko, M.O. Bublyk Cytol. Genet. 51, 40-47 (2017)

7. A. Shahi, Z. Zamani, R. Fatahi, N. Bouzari, Biochemical Systematics and Ecology 39, 826-833 (2011)

8. A. Khadivi-Khub, Z. Zamani, N. Bouzari Hortic Environ Biotechnol 49, 188-196 (2008)

9. Y. L. Cai, D. W. Cao, G. F. Zhao, 111(3), 248-254 (2007)

10. I.V. Ganopoulos, K. Kazantzis, I. Chatzicharisis Euphytica 181, 237-251 (2011)

11. S. Kato, A. Matsumoto, K. Yoshimura Tree Genetics \& Genomes 10, 477-487 (2014)

12. M. Abedian, M. Talebi, H. R. Golmohammdi, B. E. Sayed-Tabatabaei, Biochemical Systematics and Ecology 40, 112-117 (2012)

13. I.V. Stepanov, A.I. Drygina Plodovodstvo i vinogradarstvo Yuga Rossii 60 (6), 21-30 (2019)

14. I. Stepanov, I. Balapanov, A. Drygina EDP Sciences 23, (2020) 